\title{
Si trabajas en un hospital COVID-19 positivo: Recomendaciones para cuando llegas a casa
}

\section{If you work in a hospital COVID (+) recommendations when you get home}

Marisol Valle

\section{Instrucciones}

1. La puerta de tu edificio o de tu casa, es el área más contaminada, que así todo lo que te cuidaste de tocar puede estar ahí, una vez que ingresas, debería haber algún desinfectante al lado del ascensor (sobre todo si vives en un edificio, así los botones estarán más limpios).

2. Al ingresar a tu casa Intenta no tocar nada, luego puedes pasar un desinfectante por la perilla de la puerta.

3. Sácate los zapatos, déjalos afuera sobre alguna superficie con desinfectante (Figura 1).

4. Si tu mascota salió con vos deberías limpiar las patas de la misma, no te olvides que nuestras mascotas pasean por todo nuestro hogar.

5. Sácate toda la ropa externa, podes dejarla colgando en algún lugar seguro, lejos del tránsito de tu casa y luego rociarla con desinfectante, si no dispones de eso, debes lavarla, la idea es que llevemos dos capas de ropa, así nos podemos deshacer de una al ingreso.

6. Deja todas las pertenencias personales (cartera, bolso, llaves, lentes, celular) en una caja o bandeja en la puerta de casa.

7. Lávate las manos o báñate, siempre es mejor bañarse, las superficies al descubierto pueden ser muy amplias y sin darnos cuenta podemos ingre- sar al virus por una de ellas, en algunos países todavía hace calor para usar manga larga eso ayuda a transportar más el virus, nuestra piel es un vehículo (Figura 2).

8. El lavado de manos debe ser adecuado, con jabón es suficiente, mientras sea completo, abarcando todas las áreas, sobre todo las muñecas, sitio que usamos mucho para "evitar tocarnos la cara con las manos" (Figura 3).

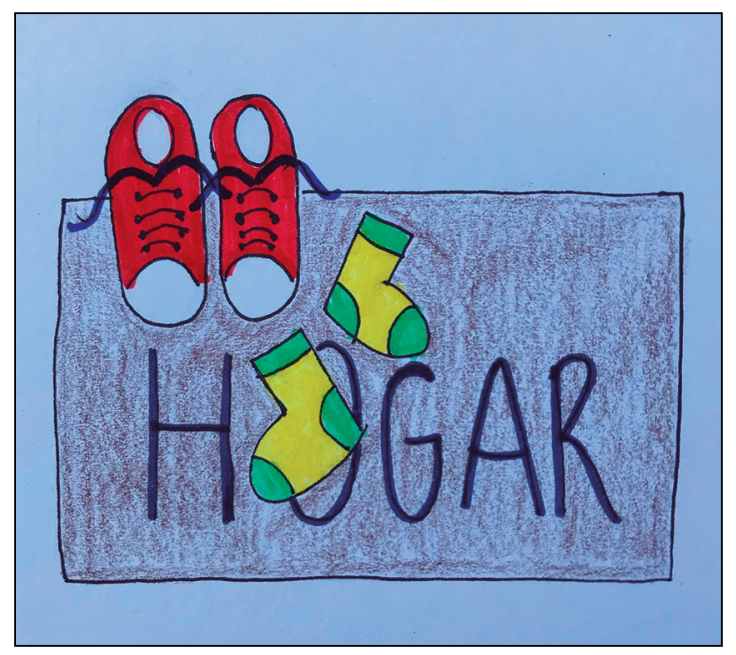

Figura 1.

Hospital Horacio Heller de la provincia de Neuquén, Argentina.

Fecha de recepción: 26 de marzo de 2020

Fecha de aceptación: 5 de abril de 2020

\section{ORCID}

https://orcid.org/0000-0002-3639-4000

Correspondencia:

Marisol Valle

Email: marisolluciavalle@gmail.com 


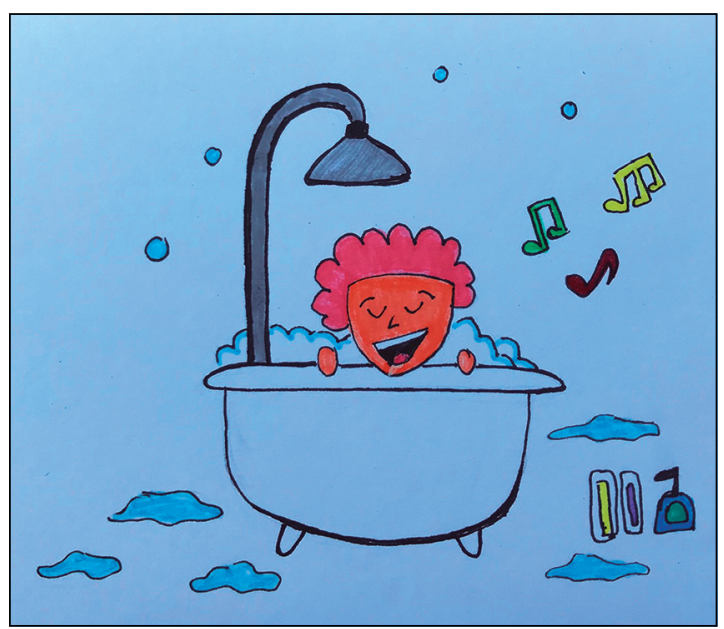

Figura 2.

9. Cualquier elemento que quieras utilizar en la casa de los que dejaste aislado en la caja, deberás desinfectarlo antes de ingresarlo al hogar. No te olvides de los lentes.

10. Si trajiste bolsas con alimentos desinféctalas también y lava cada uno de los productos que compraste, luego desinfecta el área donde estuvieron.

\section{Importante}

\section{Desinfectantes}

Es tan importante el método como el producto que usamos.

Alcohol al 70\%: Del alcohol que conseguimos en la farmacia (casi $100 \%$ ) ponemos 7 partes de agua y 3 de este, lo podemos dejar en un rociador al ingreso de la casa para su manejo útil. Al mezclarlo con agua aumenta la penetrabilidad.

\section{Lejía (cloro)}

Colocar $10 \mathrm{ml}$ en 1 litro de agua.

Ideal para lavar frutas y verduras o cualquier elemento que estemos por ingresar al hogar.

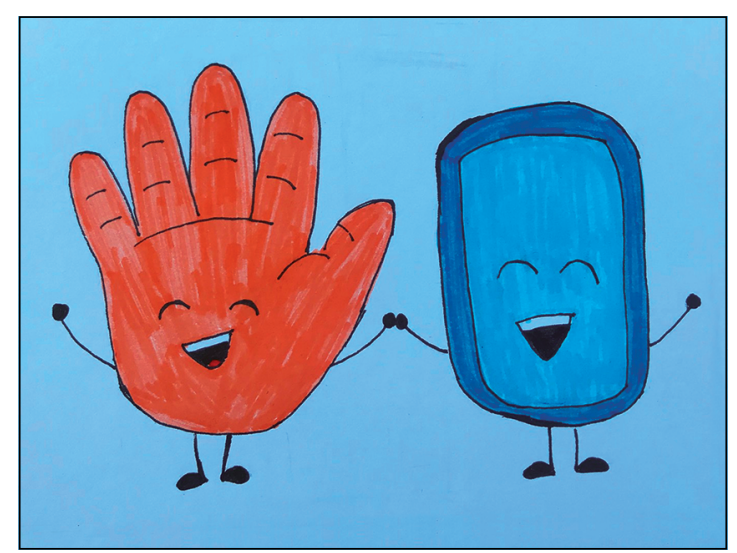

Figura 3.

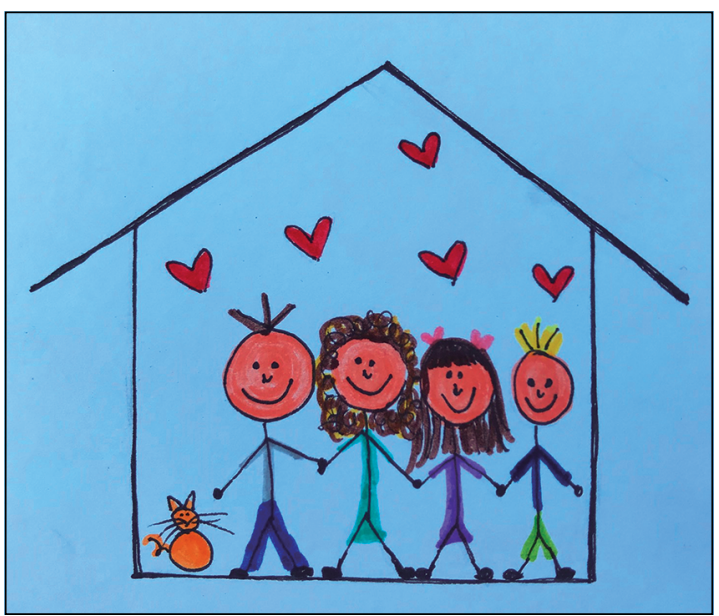

Figura 4.

\section{Recuerda dos cosas muy importantes}

1) No vas a lograr desinfectar toda tu casa, pero vas a ayudar a prevenir el contagio.

2) La medida más importante para evitar el contagio es no estar en contacto y quedándote en tu casa (Figura 4). 